\title{
Japanese Orange Fly, Bactrocera tsuneonis (Miyake) (Insecta: Diptera: Tephritidae) ${ }^{1}$
}

\author{
H. V. Weems, Jr. and T. R. Fasulo ${ }^{2}$
}

\section{Introduction}

The Japanese orange fly, Bactrocera tsuneonis (Miyake), is one of the most important pests of citrus in Japan. Extensive outbreaks have occurred in some commercial citrus areas since 1947 when up to 60 percent or more of the fruits were infested. This fruit fly has also been reported to have infested 50 percent of the oranges at Kiangtsin, in the Szechwan Province of southwestern China during 1940.

There have been no interceptions of the Japanese orange fly in the United States, probably due in a large part to the protection provided by a U.S. embargo of long standing against citrus from the orient. There have been some efforts recently to effect the removal of this embargo in order that citrus from Japan might be exported to the U.S. If this were to be done, the danger of introducing the Japanese orange fly into the U.S. would be greatly increased.

\section{Synonyms}

Tetradacus tsuneonis (Miyyake)

Dacus chenia Chen

Dacus tsuneonis Miyake

\section{Distribution}

Japan (Kyushu, Amami-O-shima Island and Ryukyu Islands), southwestern China (Szechwan and Kweichow Provinces) and probably Taiwan (White and Elson-Harris 1994).

\section{Life History}

In Japan there appears to be only one generation per year. There, adult emergence begins in early June and lasts through mid-July. Adults may be found occasionally as late as October. The ratio of males to females is approximately one to one. The preoviposition period of the female is 17 to 25 days. Oviposition occurs primarily in July and August, and

1. This document is EENY-263 (originally published as DPI Entomology Circular 56), one of a series of Featured Creatures from the Entomology and Nematology Department, Florida Cooperative Extension Service, Institute of Food and Agricultural Sciences, University of Florida. Published: January 2002. This document is also available on Featured Creatures Website at http://creatures.ifas.ufl.edu. Please visit the EDIS Website at

http://edis.ifas.ufl.edu. Additional information on these organisms, including many color photographs, is available at the Entomology and Nematology Department website at http://entnemdept.ifas.ufl.edu/.

2. H. V. Weems, Jr., Florida Department of Agriculture and Consumer Services, Division of Plant Industry; and T.R. Fasulo, Entomology and Nematology Department, Institute of Food and Agricultural Sciences, University of Florida, Gainesville, FL.

The Institute of Food and Agricultural Sciences (IFAS) is an Equal Employment Opportunity - Affirmative Action Employer authorized to provide research, educational information and other services only to individuals and institutions that function without regard to race, creed, color, religion, age, disability, sex, sexual orientation, marital status, national origin, political opinions or affiliations. For information on obtaining other extension publications, contact your county Cooperative Extension Service office. Florida Cooperative Extension Service / Institute of Food and Agricultural Sciences / University of Florida / Larry R. Arrington, Interim Dean 
eggs are laid under the rind. Thick-skinned fruit seldom are attacked as the ovipositor is not long enough to reach the pulp. Typically a single oviposition puncture is made in a fruit; from two to six eggs are deposited in a puncture from which only one larva emerges.

Larvae appear about the first of October and devour the contents of one carpel after another, from two to ten carpels being infested by a single maggot. By early November the larvae are mature, and about this time the infested fruit drops to the ground. Pupation occurs in the top two inches of soil. Occasionally larvae drop to the ground to pupate while the fruit is still on the tree.

Adults feed on honeydew excreted by aphids, coccids, and psyllids; this appears to be necessary for health, longevity, and egg production during the preoviposition period. Frequent copulation apparently is necessary, as this occurs after each batch of eggs has been deposited.

\section{Identification}

Immature stages are similar in appearance to those of other Bactrocera. Each of the two anterior spiracles of mature larvae bears approximately 34 tubules. Adults are larger than those of most other species of Bactrocera. The adult female is approximately $11 \mathrm{~mm}$ long, excluding the ovipositor, with a wing expanse of about $10 \mathrm{~mm}$; the male is slightly smaller. The head is predominately yellow, with a black ocellar triangle; antennae ochraceous, arista piceous, with yellow base. Thorax densely punctate, predominately ochraceous, with short, yellowish pubescence; a median longitudinal Y-shaped purplish testaceous streak on dorsum, terminating posteriorly in center of scutum; a pair of rather faint submedian, somewhat wavy, purplish testaceous lines, interrupted at transverse suture and united posteriorly with posterior branches of Y-shaped streak, a yellowish patch on each humeral callus; scutellum yellowish with two bristles. Halteres ochraceous. Legs ochraceous, with yellow pubescence. Abdomen densely punctate, bright ochraceous above, yellowish beneath, and brownish at end, with a short, yellowish pubescence; a longitudinal median black, rather broad, streak extends length of abdomen, or almost so; transverse bands present on third, fourth, and sometimes the fifth segment, band on third segment cross-marking longitudinal streak.

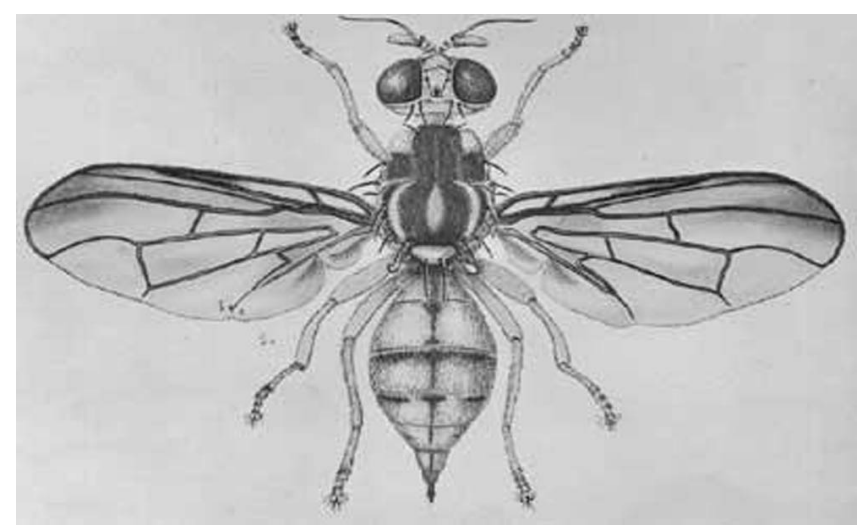

Figure 1. Adult female Japanese orange fly, Bactrocera tsuneonis (Miyake). Credits: Division of Plant Industry

\section{Hosts}

Citrus, including orange, grapefruit, and mandarin orange.

\section{Attractants}

Males are not known to be attracted to any synthetic lure (White and Elson-Harris 1994).

\section{Selected References}

Miyake T. 1919. Imperial Cent. Agricultural Experiment Station Bulletin (Tokyo) 2: 85-165, Illus. in Engl.; 1919. Review of Applied Entomology 7: 238-239.

Chen SH. 1940. Sinensia 11: 131-135; 1941. Review of Applied Entomology 29: 524.

Chen SH. 1940. Senensia 11: 577-587; 1942. Review of Applied Entomology 30: 71.

Sun CY, I-Lung D, Liao Y-M. 1958. Preliminary studies on the Chinese citrus fly, T. citri Chen. Acta Oecon, Ent. Sinica (Peking) 1: 175-187. In Chinese, English Summary

Yasumatsu, K, Nagatomi A. 1959. Kyushu Univ. Faculty of Agr. Sci. Bul. 17: 129-146. In Japanese, English Summary. 
USDA, Survey and Detection Operations, Plant Pest Control Division, Agr. Research Service.

Anonymous. 1961. Insects not known to occur in the United States. Cooperative Economic Insect Report 11-1-36. Japanese Orange Fly (Dacus tsuneonis Miyake): 29-31.

White IM, Elson-Harris MM. 1994. Fruit Flies of Economic Significance: Their Identification and Bionomics. CAB International. Oxon, UK. 601 p. 